\title{
The international protean career: four women's narratives
}

\author{
Marion Crowley-Henry \\ Lancaster University Management School, Bailrigg, Lancaster, UK, and \\ David Weir \\ CERAM, France
}

\begin{abstract}
Purpose - Using narratives from four women following international careers in France, this paper seeks to offer an insight into the depth and complexity of career issues for women working in a foreign country.

Design/methodology/approach - This is a qualitative hermeneutic inductive research undertaking on international protean careers, using in-depth interview data together with contextual information regarding the specificity of the location in question.

Findings - The concept of the protean career is highlighted in the findings. This concept is described as "having an ability to reform oneself" also referred to as "morphing". The findings in this study demonstrate how the women in the sample had the proven capability of morphing their professional role over time due to circumstance.

Research limitations/implications - The findings are limited as they cannot be generalised to a wider population due to the small sample size. However, the aim was not to generalise, but to share an in-depth collection of real-life stories from women.

Practical implications - Careers are complex, even more so on an international level. Individual choices regarding career pathways require more individualised career management approaches within organisations.
\end{abstract}

Originality/value - This research adds to the limited extant European research on women and international careers from a qualitative perspective.

Keywords Careers, Narratives, Women, Leadership

Paper type Research paper

\section{Overview}

In this paper, we share individual narratives outlining the experiences of four well-educated western women following a permanent international career in the South of France. By virtue of detailed interview transcripts and contextual information regarding the specificity of the location in question, a comprehensive picture of the experiences and choices of individual women in leadership business positions on an international level is painted. Our aim is not to generalise the findings to a wider population, but to gain an insight into the depth and complexity of career issues for women in general, and particularly for women working in a foreign country.

We highlight the concept of the protean career in our findings. This concept is increasingly described in the literature as "having an ability to reform oneself" often referred to as "morphing". The findings in this study demonstrate how the women in the sample had the proven capability of morphing their professional role as time and need required. Moreover, despite the fact that the four women portrayed in the sample were all following a more traditional career path with the same organisation, they all 
JOCM 20,2

246 underlined the need to adapt their working practices or managerial style over time and depending on their individual life stage. This shows the relevance of both the subjective and objective career dimensions on the protean career.

\section{Introduction}

In this paper, we present the international protean career of a sub-sample of four western professional women in leadership business positions living and working on a potentially permanent basis in the South of France. Using narratives (Czarniawska, 2004; Kohler Riessman, 1993), these women tell their individual career stories underlining the truly individual nature of careers where serendipity, choice and transformation play key roles. We share their career experiences and choices as they pursue their professional careers on an international level. This approach is similar to that of Czarniawska and Sevón's (2005) four life stories of foreign women professors.

The protean career concept emerged inductively from the narratives. The term "protean" has evolved from the god Proteus who was able to change form at will and morph into different objects (for example, animals) or substances (for example, fire) in order to avoid capture (Ardichvili, 2003; Arthur et al., 1999). Protean career (Hall, 1976; Fletcher, 1996; Hall and Moss, 1998; Hall and Harrington, 2004) theory focuses on the individual and her role in transforming her own career path. Hall (1976, p. 201) describes it as follows:

The protean career is a process which the person, not the organisation, is managing. It consists of all the person's varied experiences in education, training, work in several organisations, changes in occupational field, etc. The protean person's own personal career choices and search for self-fulfillment are the unifying or integrative elements in his or her life. The criterion of success is internal (psychological success), not external.

As Barley (1989, p. 49) found: "subjective careers changed with time as individuals shifted their social footing and reconstructed their past and future in order to come to terms with their present”. Our findings demonstrate how the women described, despite following a more traditional career path with the same organisation, had the proven capability of morphing and adapting their professional role over time and depending on their specific individual life stage, thus highlighting the relevance of the protean career.

The next section outlines the approach adopted for this study. This is followed by the four narratives - a summarized career history including influencing events and stages for the four interviewees in question. Next, we focus on some of the common patterns from the narratives relating to the protean career concept and leadership experiences. Finally, we draw together the narratives and the findings in discussing the implications for women choosing leadership positions. Limitations of the study and suggestions for further research are also put forward.

\section{The approach}

This paper presents the findings from a qualitative hermeneutic inductive research undertaking on international protean careers, where a total of 37 international cadres living on a potentially permanent basis in the South of France were interviewed. This core sample consists of males $(N=17)$ and females $(N=20)$ across the age spectrum (aged from 29 to 62 at the time of interview), with differing marital status 
(married $(N=22)$; long-term partner/engaged $(N=4)$; single $(N=6)$; widowed $(N=1)$; divorced $(N=4))$; with $(N=21)$ and without $(N=16)$ children. All respondents had fluent English (either as their native language or a close second language) to facilitate analysis and prevent bias or error due to translation or lack of comprehension. However, it does mean a bias toward respondents originating from the established European Union countries (pre-EU expansion to new accession countries in May 2004), the USA and Australia. All respondents could be classified as middle class/upper middle class. Since, this study was conducted in the South of France, an area associated with wealthy expatriates spending part of their year, it is necessary to differentiate the sample in this undertaking. In this study, permanently based international individuals living and working in the South of France were studied, where the work component is vital in order to sustain the continued residence of such individuals in the area.

While both men and women are included in the wider study, for the purpose of this paper, a sub-sample of four female senior managers/entrepreneurs were selected due to their professional leadership level within their respective organisations and due to the length of time they had been living in the South of France (all having lived in the area for more than ten years). They are aged between 38 and 62 . Of the four women selected, three are mothers, with their children's ages ranging from four to mid-twenties. An outline of this sub-sample is given in Table I.

Using a case study approach (Stake, 1994, 1998), where location (South of France) metaphors the organisation (Sassen (1998, 2001), King (1996, 1990), Hall (1991) and Castells (1989) regarding geographical case study research/human geographies), the geographical context of France, particularly the South of France must be emphasised here. The French social system is family-friendly with regards to its public childcare support systems (free pre-school/school from the age of three; after school child-minding facilities in schools for reduced rates; parental leave optional for up to three years where job position, title and benefits remain open to that parent (while the leave itself is unpaid by the organisation, but financially supported by the social welfare system); tax relief on the use of crèches and financial kick-backs on the use of registered child minders). The 35 hour working week which was passed into law in 2003 enforces compensation to employees working more than the 35 hour maximum limit, generally in the form of extra time off. Annual vacation in France for "cadre" employees is typically six weeks. The lifestyle of the French Riviera with its mild

\begin{tabular}{lllllll}
\hline Pseudonym & Nationality & Age & Marital status & Children & In France & Position \\
\hline Kate & British & 38 & $\begin{array}{l}\text { Married } \\
\text { (English } \\
\text { husband) }\end{array}$ & $\begin{array}{l}2 \text { (son, 6, } \\
\text { daughter, 4) }\end{array}$ & 10 years & Site manager \\
Hilda & German & 41 & $\begin{array}{l}\text { Married } \\
\text { (Spanish } \\
\text { husband) }\end{array}$ & 1 (daughter, 7) & $>10$ years & $\begin{array}{l}\text { Private sector } \\
\text { senior manager }\end{array}$ \\
Tracy & British & 54 & Widow & 2 (daughters, 21, 24) & $>10$ years & $\begin{array}{l}\text { Private sector } \\
\text { senior manager }\end{array}$ \\
Clare & American & 62 & $\begin{array}{l}\text { Divorced } \\
\text { (twice) }\end{array}$ & $\begin{array}{l}\text { None } \\
\text { (4 step-children) }\end{array}$ & $>10$ years & $\begin{array}{l}\text { Private sector } \\
\text { senior manager }\end{array}$
\end{tabular}

The international protean career

247 
JOCM 20,2 winters and very warm summers in a setting with the Mediterranean Sea for beach-lovers and the Alps for ski/snow-lovers also plays a role in painting a clearer picture of the context in which this study is set. It is an environment in which work/life balance is culturally and socially advocated.

The aim of the study is not to generalise the findings and interpretations to the wider population, but to share individual experiences and to provide an insight into the depth and complexity of career issues for women in general, and particularly for women working in a foreign country. In the following section, we relay four professional women's careers, in their own words, with their interview transcripts as the raw data. We then interpret their narratives hermeneutically and outline some of the patterns emerging from the individual stories.

\section{Kate (38, British, married, 2 children (4 and 6))}

Kate's career started after university when she followed her husband (a fellow Briton) to his first job in Scotland. She was unable to find work in languages (what she had studied) and eventually got temporary work (photocopying) via her husband in an accounts department within the same organisation. While there, luck and opportunity played a role in her progression ...

After a while, my boss said I could do an Accounting qualification. ... So that helped me to progress a bit in the Accounting department from photocopying [laugh] ... Went up to Assistant Accountant there. And then we were taken over by [international consultancy organisation] ... But it turned out the best thing for me in the world. One of my ex-bosses went for a job in London and ... he was working on an international project ... Just a small team of people. And he was looking for a linguist to come and work with him in the London office. So I went on a temporary assignment for a year down to London, still living in Scotland. I used to get up at 4.30 on a Monday morning, fly down on a 6 something flight, which they called the red eye and after a while you realise why ... And then I used to work the week in London most of the time I was travelling around Europe helping with the implementations. And then I'd fly back on the Friday night to [Scotland] ... I was there for 2 years in the end, because ... it got prolonged. I was with a team of 6 people... All the rest were managers. They'd only taken me on board because I could speak more than English and all the managers could only speak English [laugh] ... even though they were dealing with the other countries. That was the connection - it was the languages and the accounting finally coming together. And then the ... system we were deploying had a help desk here in [area in south of France]. And they asked somebody to supervise the help desk on a temporary basis for 3 months.... So I came over on a temporary basis initially, to help supervise the help desk for the product I'd just implemented. And at the end of it they said it was a full time job if I wanted to stay. So originally I said no. And [my husband] said you're an idiot. And he gave up his job in England. . .

Kate accredits her career progression to luck/serendipity - by being in the right place at the right time and to her having the right skills necessary at that particular time (her technical experience in languages and accountancy). Her move to senior management when she moved to France was supported by her husband who quit his own fast-track career in the UK to move with her to France. They both felt that the quality of life (escaping the commuting nightmare in the UK), the weather and environment on offer in the South of France was not an opportunity to be ignored.

Kate's career progressed rapidly in France, aided by structural forces (company reorganisation) and serendipity (her boss moved geographically and she was offered his position): 
Within a year and a half I became manager of the whole helpdesk. ... We actually doubled the size of the office. I think the maximum we were was 75 . So I started running the [whole site] office.

Kate is one example in the sample where she believes her career to have progressed more by virtue of her being an international manager. Her choice to move however was not just career contingent, but also came about thanks to her husband's support and their wider life picture of what living in the South of France would mean to them both as regards quality of life. This underpins the protean career concept. Kate stresses the value of the French child support system in enabling her to maintain and grow her management position. With a mixture of spousal support, state childcare (subsidised crèches, after school care) and external support (child minder), she was able to focus on her career.

While Kate personally feels her career has progressed in the organisation to a greater extent than she could have planned, and that she has not experienced gender discrimination as such, she does feel that men often get promotional opportunities easier by virtue of their membership in internal organisation networks. She explains:

I mean I kind of hit a barrier but I think it's more because of the way men and women work. Because my equal in the US running the other half of the help desk, he in the end was promoted over me to take care of the call centres world wide in the last year. And I was miffed that he'd got it rather than me. But the way he worked, he was more into the politics of it than me. He knew who to talk to, what to do to be seen and all the rest of it, whereas I wasn't very good at that ... I'd get on and do things; do the job and deal with it and be even more worried about the people below. He spent a lot more time on the politics and showing what he was doing, where I wasn't particularly good at doing that - marketing myself I guess ... I think it's a male thing. I don't know. I think it's not a natural woman trait. It goes back to the nurture thing - that women are more/better at the nurturing below.

\section{Hilda (41, German, married, 1 daughter (7))}

Hilda moved to the South of France after her high school studies in Germany, with the initial intention to learn French and take a year out before returning to study in Germany. However, having overcome the initial challenges of settling into the region, she went on to study in France and the years just rolled by. She is now over 20 years in the area:

I think living in a foreign country is very difficult in the first year and when you have managed to go over the first year... - [for me] at the time I was 20, I was quite proud of having organised my life here with friends and language and then I thought I would stay another year. And then another year. And then another year [laugh]. Now it's over 20 years.

While she studied French in France, planning to become a German teacher in France, structural forces forced her to morph her career options. She learned that it was not possible to become a teacher in France without being French. By chance (muddling through, serendipity), she heard about (private sector IT Travel organisation) opening up and loved the whole concept of working there. She explains:

And so I studied in France, first to become a German teacher and then I heard about [private sector IT Travel organisation] which was not yet built and I was very interested because it was a company regrouping everything I always liked - different nationalities, tourism, information technology, different languages ... And then I continued studying information technology with the idea of joining [private sector IT Travel organisation].

\section{The international protean career}


JOCM 20,2

\section{0}

She proactively planned her education to give her the best opportunity of joining (private sector IT Travel organisation), which worked out because she "joined [private sector IT Travel organisation] as a trainee and then they hired me".

From the humble organisational career beginnings of a trainee, Hilda has progressed in the organisation thanks to her technical skills and internal mobility opportunities:

So I was a trainee and I started in quite an exciting phase at [private sector IT Travel organisation] because we were not yet on production. So we were still a project and everything was ... very very exciting ... I really have the feeling I participated and brought something ... I was a trainee for 4 months and then I was hired and I continued the same job ... So it was quite exciting and I did a lot of travel at the beginning ... Then I got the recommendation to change groups, to do a bit more cross functional work before moving in the hierarchy ... Then I got pregnant, so I left, had my baby and on the day that I came back from maternity leave I was promoted ... Which I think is quite a good move for [private sector IT Travel organisation]. Actually I came back to the previous group and I was then manager of this group ... So I stayed in that group a couple of years and then I moved to another group, so still at the same level to another group ... I got more functionality in the group and more people. And now since April I've been promoted to senior manager and I have expanded further and further the group and the responsibilities.

Hilda realises she was lucky in that having her child did not detract from her career progression in the organisation. On the contrary, she was promoted the day she returned from maternity leave. Hilda compliments the French social support system in accommodating career women with children:

I was convinced that I wanted to come back to work. So when you are convinced and you are positive about working and having a child I think it's easier. I had no bad feelings at the time. And we had a nanny at home for the first year ... and then we decided to bring [our child] to a nanny ... And that was close to [work], so that was not so bad to get to work and bring [the child] and then afterwards to pick [the child] up ... I had some restrictions; latest I could go to pick [the child] up was at 6.30. But it was quite ok. And with my husband we normally can arrange ourselves so either one was coming early and then leaving early and the other one was staying a bit later ... I stopped travelling. Well I reduced travelling quite a lot.

Spousal support in sharing the childcare responsibilities was essential in Hilda being able to maintain her career momentum during her daughter's early years: "It's very important, otherwise it's not manageable. You cannot have children and a career if you don't have support from your partner."

While Hilda is ambitious in her professional career and would like to continue to progress vertically in the organisation, she admits that timing plays a key role, and right now may not be the best time for her to put all her energies into advancing her career:

I think I would have a bit more ambition to move forward. I'm not so sure whether right now at this very moment I want to be a director. It's quite a lot of work and I need to keep a bit of a place for my family.

She puts her family first, although, she admits, it may not seem so some times when she is working hard. Nevertheless, she does believe family has to come first, or else what is it all for. 
Hilda has not personally suffered gender inequality in the organisation, but she does notice that most of the top management are French men that have attended grandes écoles (elite French third level education schools). Nonetheless, she has not personally encountered any discrimination in her career progression within the organisation to date, which could be due to her French third level education (although not in a grande école) in a technical subject, and her fluency in French. She perceives the value of networking in order to get things done as highly visible in the organisation - "In [private sector IT Travel organisation] you get more done or easier done when you know people. So that's my own experience."

She is now following a traditional organisational career after having morphed her career direction from German teacher to private sector management, stressing that the French childcare system and partner support in childcare have played a large part in her ability to focus on her career.

\section{Tracy (54, British, widow, 2 daughters $(21,24))$}

Born and raised in Britain to a French mother and an Italian father, Tracy was raised multi-culturally: bilingual French/English and studying for one year in the USA during high school. She continues:

Went to college ... No brilliant studies, I just got my HSD in Business Studies. And then went to Brussels for [international company A's] ... European Headquarters and was there for 2 years. Then decided I wanted to work in a ski resort but with a proper job ... So I got a job in Marketing for [a ski resort in the French Alps] and I was there for 5 years doing the contracts with the tour operators ... During which time I met my husband who lived in [United States]. So we got married ... and then I went to the States. I was in the States for nearly 12 years. Sadly my husband died after we'd been married for 7 years ... by which time I'd already started my own travel agency and tour operating company. So I had that for 9 or 10 years. And then sold it, became a branch office of a larger travel agency that had branches all over the United States. I stayed on for a year with a Management contract, as branch manager ... And then I joined [company B] ... in Product Development, not being at all technical and I was very surprised that they hired me. I went there and that was just at the time that [private sector IT Travel organisation], the company I'm with currently, was starting up. I was attached to the [private sector IT Travel organisation] contract from the [company B] side. And very quickly as I spoke fluent French, I was asked if I'd like to join [private sector IT Travel organisation]. And my children were 5 and 8 at the time and I thought it would be nice to bring them up in France, bilingual. So we came to [area in south of France] ... and I worked in Product Management ... just as a team member and then gradually evolved into different management positions. [In my current position] I have a small team of 5 permanent [private sector IT Travel organisation] staff members plus 3 students and then 6 to 8 outsource staff who work in the centre itself; so it's a team of about 14. And I'm a senior manager which is sort of as far as one can go before moving up to director level.

A culmination of life factors influenced her move to France such as being half French and fluent in the language, her husband's death leaving her a single mother of two young children, the opportunity to return to Europe at an organisation's expense (it would have been too expensive to move herself), the opportunity for her children to be reared bilingual, and the serendipitous situation of being offered the job. She admits:

... it was professional reasons that brought me here to France. So that was the job offer from [private sector IT Travel organisation]. And it would have been terribly expensive to think of moving house, well I hadn't even thought of moving back to Europe quite frankly.

\section{The international protean career}

251 
JOCM 20,2

I'm not a US citizen, but I had a green card and I was very happy in the States. We were fine in the States. So there was no reason to think of moving back. And if [private sector IT Travel organisation] hadn't come along, I'd probably still be there.

Tracy's story presents the role of chance, of serendipitously being at the right place in the right time, in setting up an individual's career direction.

However, Tracy complains about her stagnation in the vertical career progression in the organisation:

I've been at [current level] for 3 years now and I asked if there'd be consideration for promotion this [year] ... and I didn't get it. But you never know why. I mean I got a fabulous evaluation ... Then you hear: 'well unemployment is so high. You should be happy that you have a job'. If you complain about the stress, then ... you hear: 'people who are unemployed you know would like to have the stress that you're saying you've got'.

In the structural market environment of redundancies, Tracy is made to feel she should be grateful for being at the level she is. However, she is sure that:

Oh my career would have progressed much more if I had stayed in the States. Here, in France they look at your personal situation too much. When I was first hired by [private sector IT Travel organisation] in the US, no one knew or asked about my personal situation. They didn't know I was a single mother, widowed with 2 very young [children]. That was private. I don't think I'd have been hired in France in the same situation. Because here they want to know your personal situation; they see it as relevant. Everyone wants to know your business. But I don't think it is relevant for the job. If you are able to do the job and want to do the job, then your personal situation should not matter.

She feels discriminated on the basis of her gender and on the French educational networking front:

Oh networking is so important for your career. Men in France that went to the same grande école [elite French third level education school] and mixed in the same social circles ... That is the barrier for non-French here.

Tracy's career has evolved over time from her love of travelling and working abroad to her entry into tourism and the move to (private sector IT travel organisation). Her career has progressed vertically over time, but she fears that her progression has halted for the moment. Owing to her personal circumstances (widowed mother of two young children in the initial stages in her career) she has had to work in order to provide for her family. Her career does not take a backseat but is the forerunner in the family. She values the lifestyle she has in France with the weather, her children being bilingual, while noting her professional career would have progressed more had she remained in the USA, away from the seemingly discriminatory culture in France (as she perceives it). However, work/life balance is important to her and in weighing up all the career factors (location, children, technical job ...) she would not leave the location in furtherance of a professional career elsewhere, again emphasising the relevance of the protean career in career planning and decision making.

\section{Clare (62, American, divorced)}

Clare's career has been at a senior organisational level for quite a long period. She chose to follow an international career due to her personal history, having been raised in Europe. She explains: 
I was raised in Europe as a child. ... and then [I] returned to the US. My father sent me back there to go to university because I really had no exposure to the US except for home leave and that would be for a few months every 3 years and so I was very unfamiliar. And it was truly a culture shock. I would say for the first 2 years it was extremely difficult. Anyway, so I went to ... a very small girl's school which is now a university ... Then I joined [airline carrier] and I flew as a flight attendant for 13 years and I had the whole travel bug. But when I was with [airline carrier] - I spent 26 years with them - I went into management in Training. So I've been wearing a training hat, oh gosh, frightening, since 1973 ... I started with flight service training which is training the flight attendants. And then I moved into Sales, Marketing, Management ... I was then made Director of Training and I managed the people who trained all aspects of the airline operation. ... I left training at [airline carrier] and was a station manager for 9 months. It was kind of like I wanted to put into practice everything that we had been teaching other people to do. And what I found was that I really didn't enjoy it at all. [laugh]. It was exciting, you know, but airplanes come, airplanes go and you have to react to each flight. But it wasn't the kind of work that I was accustomed to where I was managing people on a daily basis and there was a continuity that one could actually see. So a friend of mine that used to work for me at [airline carrier] had joined this brand new company called [private sector IT Travel organisation] in ... and she said they're looking for a training manager. And I said yippee, I'm ready to go back where I'm most comfortable. And so I interviewed, they hired me the same day and 2 weeks later - boom there I was. And then we moved. It was part of the job that I move and this certainly was something that influenced me. I knew that even though we would spend a few months in [location in USA], everyone was returning to [area in south of France] because this was our base. So I was hired as a French employee, which I am today. So that's why I came. It was very important for me to move back to Europe. ... It was my childhood ... I don't think that I was excited about it professionally because I was going back into something that I had already done for many many years. I didn't know at the time what a challenge it would be. Because it was a brand new company. ... So that turned out to be a bonus that I never expected to do something from nothing. It was challenging to say the least, but very rewarding.

Clare had an innate desire to return to Europe and was glad to follow an organisational career path that enabled her to do that. She progressed vertically in (airline carrier) through opportunity, serendipity (right place, right time, right skills), and hard work. Encouraged by structural forces (airline carrier going into liquidation) she moved to a different position which she did not really like (as station manager) and through social capital (networking) she heard about the opening for the position in (private sector IT Travel organisation) where her lifelong career experience as training manager/director at (airline carrier) could be pursued, but in a different environment. She was able to use her past experiences (technically on the job front; culturally having been raised in Europe) in forming her career identity for (private sector IT Travel organisation). While the move may have been lateral in terms of the position, it was the lifestyle opportunity that a return to Europe offered her which led to her decision to join (private sector IT Travel organisation), again stressing the protean career concept of professional careers being determined by many factors.

She notes the difference between gender opportunity for progression at (airline carrier) and (private sector IT Travel organisation). At (airline carrier):

... the glass ceiling was there. I mean we had one female vice president. There is no question that that was a barrier... [However] she promoted a lot of females to higher levels than they had been before... It existed but it wasn't obvious, which is a big contrast here, where it's very much a French company in its mentality... I suppose you could [take up any grievance

\section{The international protean career}

253 
JOCM 20,2

254 for gender discrimination] but that would be the kiss of death really... And the way I do it it's my job that's important and as long as I can accomplish what I need to accomplish that's fine.

Clare does not wish to rock the boat in the organisation. While acknowledging they perceive that gender inequality exists with regards to progression in the organisation, neither Hilda nor Clare want to force the issue, but are willing to accept their lot and be happy with the positions they have. However, Clare admits that were she younger in her career, she may be more willing to fight the system in breaking the perceived glass ceiling for international women in the organisation:

I mean at my age now it's not worth fighting. It's just not worth it. And I do get enough satisfaction from my job. And I'm recognized for what I do. I wouldn't say it's fantastic, but it's OK. But for the younger women it is extremely frustrating.

As with all the women in this paper, Clare also notes the French social support for women with children as a key advantage enabling women to follow their careers in France:

There's so much support. Half the women in this group and I have almost 60 people in the group, well at least half of the women have children and the trainers in particular I mean they have to go off and travel all the time... And they work part time ... I mean the law here is very strict about that. So there's no sort of discrimination because you have a child ... Here, in this country it's particularly manageable because of the support that the state actually gives mothers. And more and more because the cost of living here is going up, there are 2 household workers. You know both people have to work. And so they have to have that ability to have support.

To sum up Clare's career - while she moved up the vertical ladder in her career at (airline carrier), she feels she has not progressed much further in her current organisation. However, she is not willing to undergo the stress of fighting the system at this stage in her life. She values her protean career more than her objective career, where the sum of factors influencing her career (such as location, travel opportunities, peace of mind) takes priority over hierarchical position in the organisation.

\section{Patterns among female international protean career proponents}

The stories relayed here are from four different international women that have settled in the South of France and are following an international career in the area. All four of them are senior managers in a multinational organisation, in leadership positions where they have an influencing role over others. They all have their own career stories, as indeed do each of the other 33 interviewees in the wider study that were not presented in this paper. This section focuses on some of the patterns that have emerged from the four narratives shared here.

The complexity of decisions and choice-factors in constructing a professional career is highlighted in the narratives presented in this paper. While it can be assumed that this complexity runs through for both male and females, this study has focused on the female perception of their career progression and choices. In this regard, the women surveyed have emphasised the relevance of support (from partner/spouse, from external help (childminder), from the state (childcare subvention) in being able to balance a professional career and children. 
Interestingly, those women surveyed have all stressed that they do not place their professional careers at the top of their priority list, but put their family/personal life there first. This sample have all chosen to live in the South of France for lifestyle reasons (Schein's (1978) lifestyle anchor), despite some perceiving their professional careers would have progressed more had they remained in their home countries. Thus, it can be assumed that the sample is in that way skewed towards those placing more emphasis on the life element of the work/life balance.

Structural forces and serendipity were also noted by the women in factors leading to their career progression. Being in the right place at the right time with the right skills was a key element in opening career opportunities. Social capital and the importance of having a good relationship with your manager were also given as contributing factors in career progression. It was noted that males seem to have easier access to career networking opportunities, and that in particular, in France, not being a member of the grande école educational elite club was perceived as being a disadvantage in organisational career progression, given that the most senior management in the organisation were French males with a grande école background. In our analysis, the women in question had experienced varying degrees of discrimination in their organisational life in France, suggesting the individual perception of gender equality is culturally and subjectively influenced (Czarniawska and Calás's (1997) comparative analysis of international students' interpretations of discrimination which showed that "culture" was commonly explained as the factor determining the extent of gender discrimination).

These afore-mentioned elements all play a part in the choices available and opportunities open to women in their career advancement. Depending on the respective life-stage, women given the same career opportunities may opt for a less challenging role in order to better manage the home/work life balance (as in Hilda's case). Others may be more open to taking on additional responsibilities despite having young children due to the support they are receiving from their spouses/from the social system (notably Kate, also Hilda). While others again may choose to focus primarily on their careers (such as Tracy and Clare) due to personal circumstances (Tracy, as a young widow, being the sole financial provider for her family; Clare not having any children herself). Nonetheless, the protean career concept underlines each case shared here. The ability to transform as time determined the life focus from career to children to changing career direction is noticeable in the narratives.

\section{Implications for women choosing leadership positions}

While Adler $(1986,1987)$ notes that women in international management often succeed due to their exotic or international status (with their gender being down-played), this study has shown that the traditional role divisions (woman with children faces most of the child rearing responsibility) still exist. Despite social support existing in France, the culture is still quite patriarchal as regards senior leadership positions, with membership of the top leadership club restricted primarily to French males having gone through the same educational system. However, females and indeed international females are breaking the glass ceiling, but at an evolving, gradual as opposed to a revolutionary pace. Timing, opportunity and structural forces work together to facilitate this change.

\section{The international protean career}

255 
JOCM 20,2
The importance of structure and agency (Giddens, 1979, 1993; Goodwin, 1999) in attaining leadership positions must also be stressed. The individual choices (agency) that women make in order to pursue their professional career is but one part of the wider picture. The structural forces (such as the market conditions, external support available) also determine the opportunities available. Thus, it appears to be not so much a question of direction of control coming from the organisation (from traditional HR functions on career progression for instance), but a question of individual pathways: individuals making choices and managing routes, making the best of their particular circumstances at that particular point in time.

\section{Limitations of the study and suggestions for further research}

This paper shares the narratives of a sub-sample of international career women living in the South of France. It is part of a wider research undertaking on international careers. The contextual environment of the South of France and the case study approach adopted in this paper (mini-cases of individual women's careers) renders this study very specific and difficult to generalise to the wider population. This is the main limitation of the case study approach. However, as stated at the outset, the aim of this paper is to deepen understanding of the complex nature of careers by sharing narratives from individuals concerning their career paths. While it is clear that every individual's story is different, common threads do arise, which were shared in the previous section. The approach adopted here has been qualitative in nature in order to uncover experiences through life stories, which we believe to be the best way in approaching this subject in order to deepen the understanding of the complexity of this area.

We suggest that further case studies be adopted in examining women in leadership positions. There is a need for a wider view of careers - the whole life picture encompassing the sacrifices and supports that successful women leaders have encountered and which have facilitated their successes.

Similarly, a cross-country perspective on international women following their professional careers in different countries would be an interesting comparative study. Furthermore, detailed life histories of women in domestic leadership positions should also provide vital information as to the structure and agency forces at play.

\section{Conclusions}

In this paper, emphasis is placed on the individual experiences of a selection of four international women in leadership positions (with people management responsibility). The sample is special insofar as the women in question are all working in a country which is not their home country (South of France), and have been in that host country for a substantial length of time (over ten years). Their career related experiences as regards their gender and their nationality were reviewed on an individual basis. This is in keeping with Truty (2003, p. 216, italics added) who called:

... attention to unique perspectives among workers and reassert[ed] that "worker" does not denote a categorical monolith, but rather a unique human being who perceives the same phenomena differently from everyone else.

The goal of this paper is to deepen understanding of the issues facing women following an international career, a career that began for some as a trailing spouse; for others as 
a career/new life opportunity. The protean nature of the careers in question has been outlined and discussed throughout the paper. The importance of taking a protean approach to careers has been stressed - where a wider approach to careers is required in order to fully understand the choices and opportunities open to women wanting to pursue leadership career positions.

\section{References}

Adler, N.J. (1986), "Women in management worldwide", International Studies of Management \& Organization, Vol. 16 Nos 3/4, pp. 3-32.

Adler, N.J. (1987), "Pacific basin managers: a gaijin, not a woman", Human Resource Management, Vol. 26 No. 2, pp. 169-92.

Ardichvili, A. (2003), "Constructing socially situated learning experiences in human resource development: an activity theory perspective", Human Resource Development International, Vol. 6 No. 1, pp. 5-20.

Arthur, M.B., Inkson, K. and Pringle, J.K. (1999), The New Careers: Individual Action and Economic Change, Sage, Thousand Oaks, CA.

Barley, S.R. (1989), "Careers, identities and institutions: the legacy of the Chicago School of Sociology", in Arthur, M.B., Hall, D.T. and Lawrence, B.S. (Eds), The Handbook of Career Theory, Cambridge University Press, Cambridge.

Castells, M. (1989), The Informational City, Blackwell, London.

Czarniawska, B. (2004), Narratives in Social Science Research, Sage, London.

Czarniawska, B. and Calás, M. (1997), “Another country: explaining gender. Discrimination with "culture”, Administrative Studies, Vol. 4, pp. 326-41.

Czarniawska, B. and Sevón, G. (2005), "The thin end of the wedge. Foreign women professors as double strangers in academia", Gothenburg Research Institute (GRI-rapport 2005:7), Göteborg, available at: www.handels.gu.se/epc/archive/00004461/

Fletcher, J.K. (1996), "A relational approach to the protean worker", in Hall, D.T. et al. (Eds), The Career is Dead - Long Live the Career, Jossey-Bass, San Francisco, CA, pp. 105-31.

Giddens, A. (1979), Central Problems in Social Theory: Action, Structure and Contradiction in Social Analysis, Macmillan, London.

Giddens, A. (1993), New Rules of Sociological Method, Polity Press, Cambridge, MA.

Goodwin, M. (1999), "Structure-agency", in Cloke, P., Crang, P. and Goodwin, M. (Eds), Introducing Human Geographies, Chapter No. 4, Arnold, London, pp. 35-42.

Hall, D.T. (1976), Careers in Organisations, Goodyear/Scott/Foresman, Santa Monica, CA/Glenview, IL.

Hall, S. (1991), "The local and the global: globalization and ethnicity", in King, A.D. (Ed.), Culture, Globalization and the World-System: Contemporary Conditions for the Representation of Identity. Current Debates in Art History 3, Department of Art and Art History, State University of New York, Binghamton, NY.

Hall, D.T. and Harrington, B. (2004), "The protean career. A sloan work and family encyclopedia entry", available at: www.bc.edy/bc_org/avp/wfnetwork/rtf/wfpedia/wfpPCARent.html (accessed 21 March).

Hall, D.T. and Moss, J.E. (1998), "The new protean career contract: helping organizations and employees adapt”, Organizational Dynamics, Vol. 26 No. 3, pp. 22-37.

\section{The international protean career}

257 
JOCM

20,2
King, A.D. (1990), Urbanism, Colonialism, and the World Economy: Culture and Spatial Foundations of the World Urban System, The International Library of Sociology, Routledge, London/New York.

King, A.D. (Ed.) (1996), Representing the City: Ethnicity, Capital and Culture in the 21st Century, Macmillan, London.

Kohler Riessman, C. (1993), Narrative Analysis. Qualitative Research Methods Series 30, Sage, Newbury Park, CA.

Sassen, S. (1998), Globalization and its Discontents, New Press, New York, NY.

Sassen, S. (2001), "The global city: strategic site/new frontier, saved under India Seminar 2001", available at: www.india-seminar.com/2001/503/503\%20saskia\%20sassen.htm (accessed 2 October 2005).

Schein, E.H. (1978), Career Dynamics: Matching Individual and Organizational Needs, Addison-Wesley, Reading, MA.

Stake, R.E. (1994), “Case studies”, in Denzin, N. and Lincoln, Y.S. (Eds), Handbook of Qualitative Research, Sage, Thousand Oaks, CA, pp. 236-47.

Stake, R.E. (1998), "Case studies”, in Denzin, N. and Lincoln, Y.S. (Eds), Strategies of Qualitative Inquiry, Sage, Thousand Oaks, CA, pp. 86-109.

Truty, D. (2003), "Challenging the lure of the protean career", paper presented at the 2003 Midwest Research to Practice Conference in Adult, Continuing, and Community Education, Ohio, 8-10 October, pp. 216-22.

\section{Further reading}

De Cieri, H., Dowling, P.J. and Taylor, K.F. (1991), "The psychological impact of expatriate relocation on partners", International Journal of Human Resource Management, Vol. 2 No. 3, pp. 377-414.

Graham, S. and Marvin, S. (1996), Telecommunications and the City: Electronic Spaces, Urban Places, Routledge, London.

Stone, R.J. (1991), "Expatriate selection and failure", Human Resource Planning, Vol. 14 No. 1, pp. 9-18.

\section{Corresponding author}

Marion Crowley-Henry can be contacted at: m.crowley@lancaster.ac.uk; marian_crowley@ hotmail.com

To purchase reprints of this article please e-mail: reprints@emeraldinsight.com Or visit our web site for further details: www.emeraldinsight.com/reprints 